\author{
${ }^{1}$ T.M. Aldibekov ${ }^{(D)},{ }^{2}$ M.M. Aldazharova \\ ${ }^{1}$ Doctor of Physical and Mathematical Sciences, Prof., E-mail: tamash59@mail.ru \\ ${ }^{2} \mathrm{PhD}$, E-mail: a_maira77@mail.ru \\ Al-Farabi Kazakh National University, Almaty, Kazakhstan
}

\title{
ON A DIAGONAL SYSTEM OF THE FIRST-ORDER PARTIAL DIFFERENTIAL EQUATIONS FROM TWO INDEPENDENT VARIABLES
}

A diagonal system of three first-order partial differential equations in two independent variables is considered. The equations entering into the diagonal system are independent from each other, therefore, the compatibility condition of the system does not arise. We consider the asymptotic behavior of solutions at an infinitely distant point, with respect to some parameter. The main place in the system is occupied by a nonlinear first-order partial differential equation, the remaining equations are adjoining equations, the solutions of which contain the initial value of one independent variable as a parameter. The attached equations are chosen appropriately, and the solution to the system is already studied, which already has an internal connection. The adjoint equations are linear first-order partial differential equations. Using the fact that the zero solutions of the characteristic equations are asymptotically stable on Lyapunov, the conditions when the set of three differential equations, considered as a diagonal system of partial differential equations of the first order, has a solution with certain initial values and is an infinitesimal function in the vicinity of an infinitely remote point are described. Methods of the theory of functions and differential inequalities in the theory of first-order differential equations are used.

Key words:differential equations, diagonal system, first order partial derivatives, asymptotic behavior.

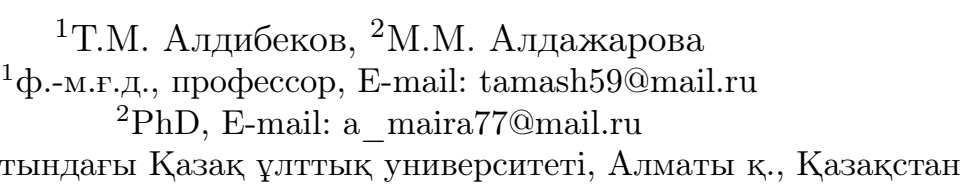

Екі тәуелсіз айнымалы бойынша бірінші ретті дербес туындылы дифференциалдық теңдеулердің диагональдық жүйесі туралы

Екі тәуелсіз айнымалы бойынша үш теңдеуден тұратын бірінші ретті дербес туындылы дифференциалдық теңдеулердің жүйесі қарастырылады. Диагоналдық жүйеге кіретін теңдеулер бір-бірінен тәуелсіз болғандықтан, жүйенің үйлесімділік шартының қажеті болмайды. Қандай да бір параметр бойынша шексіз алыс нүктедегі шешімнің асимптотикалық тәртібі қарастырылады. Жүйедегі негізгі орында, бірінші ретті дербес туындылы бейсызықты дифференциалдық теңдеу болып табылады, қалған екі теңдеулер шешімдері бір тәуелсіз айнымалының алғашқы мәнін параметр ретінде қарастыратын, үлестегі бірінші ретті дербес туындылы дифференциалдық теңдеулер болып табылады. Үлестегі бірінші ретті дербес туындылы дифференциалдық теңдеулер ыңғайлы түрде таңдап алынады да, енді ішкі байланыстары бар теңдеулерден тұратын жүйенің шешімі оқып зерттеледі. Үлестегі теңдеулер бірінші ретті дербес туындылы сызықты дифференциалдық теңдеулер болып табылады. Олардың сәйкес сипаттауыш теңдеулерінің нөлдік шешімдерінің Ляпунов бойынша асимптотикалық орнықтылықтарын пайдаланып, анықталған белгілі бір алғашқы мәндерімен берілген үш дифференциалдық теңдеудің жиынтығы, бірінші ретті дербес туындылы дифференциалдық теңдеулердің диагоналдық жүйесі түрінде қарастырылып, шексіз алыстағы нүктенің аймағында шешімі шексіз аз функция болатын шарттар сипатталған. Функциялар теориясының және бірінші ретті дербес туындылы дифференциалдық теңдеулер теориясының тәсілдері қолданылған.

Түйін сөздер: дифференциалдық теңдеулер, диагоналдық жүйе, дербес туындылар бірінші ретті, асимптотикалық тәртіп. 


\author{
${ }^{1}$ Т.М. Алдибеков , ${ }^{2}$ М.М. Алдажарова

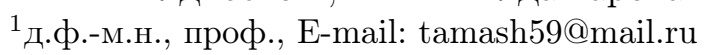 \\ ${ }^{2} \mathrm{PhD}$, E-mail: a_maira77@mail.ru
}

Казахский национальный университет имени аль-Фараби, г. Алматы, Казахстан

Об одной диагональной системе дифференциальных уравнений с частными производными первого порядка от двух независимых переменных

\begin{abstract}
Рассматривается диагональная система из трех дифференциальных уравнений с частными производными первого порядка от двух независимых переменных. Уравнения, входящие в диагональную систему друг от друга независимы, поэтому условия совместимости системы не возникает. Рассматривается асимптотическое поведение решений на бесконечно удаленной точке, относительно некоторого параметра. Основное место в системе занимает нелинейное дифференциальное уравнение с частными производными первого порядка, остальные уравнения являются присоединенными уравнениями, решения которых содержат начальное значение одного независимого переменного как параметр. Присоединенные уравнения выбираются подходящим образом, и изучается решение системы, уже имеющее внутреннюю связь. Присоединенные уравнения являются линейными дифференциальными уравнениями с частными производными первого порядка. Используя, что нулевые решения характеристических уравнений являются асимптотически устойчивыми по Ляпунову, описываются условия, когда совокупность трех дифференциальных уравнений, рассматриваемых как диагональная система дифференциальных уравнений с частными производными первого порядка имеет решение с определенными начальными значениями и является бесконечно малой функцией в окрестности бесконечно удаленной точки. Применяются методы теории функций и дифференциальных неравенств в теории дифференциальных уравнений с частными производными первого порядка.

Ключевые слова: дифференциальные уравнения, диагональная система, частные производные первого порядка, асимптотическое поведение.
\end{abstract}

\title{
1 Introduction
}

Without pretending to completeness, we note some works, whose interests more or less intersect with questions on the subject of discussion. As known, the problems of a differential equation with first-order partial derivatives in the analytical case were considered in [1-2]. The first- order partial differential equations in the nonanalytic case were considered in [3-7]. There is a guide to first-order partial differential equations [8]. Also note some useful works under the subject of investigation [9-22]. Some information on the subject is available in books [23-29].

The study of system of the first-order partial differential equations in the nonlinear case is a difficult task, since, generally speaking, the characteristic system is not developed. The paper considers a certain diagonal system of the first-order partial differential equations, which arises as a result of differential inequalities. Using the methods of the theory of functions and differential inequalities in the theory of the first-order partial differential equations, the behavior of the solution is studied.

\section{Materials and research methods}

On the plane of variables $(x, y) \in \mathbb{R}^{2}$, the set

$$
S=((x, y): 0 \leq x<+\infty, c-L x \leq y \leq d+L x)
$$


is defined, where $c<0, L>0, d>0$. The first-order diagonal system of partial differential equations is considered

$$
\left\{\begin{array}{c}
\frac{\partial \theta}{\partial x}=\left(b_{1}(x) y+h_{1}(x, y)\right) \frac{\partial \theta}{\partial y} \\
\frac{\partial u}{\partial x}=\left(b_{2}(x) y+h_{2}\left(x, y, u, \frac{\partial u}{\partial y}\right)\right) \frac{\partial u}{\partial y} \\
\frac{\partial \nu}{\partial x}=\left(b_{3}(x) y+h_{3}(x, y)\right) \frac{\partial \nu}{\partial y}
\end{array}\right.
$$

$\left(b_{1}(x) y+h_{1}(x, y)\right) \frac{\partial \theta}{\partial y} \in \mathbb{C}^{2}(E)$,

$\left(b_{2}(x) y+h_{2}\left(x, y, u, \frac{\partial u}{\partial y}\right)\right) \frac{\partial u}{\partial y} \in \mathbb{C}^{2}(E)$,

$\left(b_{3}(x) y+h_{3}(x, y)\right) \frac{\partial \nu}{\partial y} \in \mathbb{C}^{2}(E)$; where $E$ is a convex domain in $\mathbb{R}^{4}$ containing the point 0 , the projection of which onto the $(x, y)$-plane contains $S$. Denote by $I \equiv[0,+\infty)$. The variable $x \in I$.

The diagonal system (1) is considered with initial values

$$
\left\{\begin{array}{cc}
\theta(0, y)=\omega_{1}(y), \omega_{1}(y) \in \mathbb{C}^{2} \\
u(0, y)=\varphi(y), \varphi(y) \in \mathbb{C}^{2} \\
\nu(0, y)=\omega_{2}(y), \omega_{2}(y) \in \mathbb{C}^{2}
\end{array}\right.
$$

where $y \in(c, d)$;

The equation

$$
\frac{\partial \theta}{\partial x}=\left(b_{1}(x) y+h_{1}(x, y)\right) \frac{\partial \theta}{\partial y}
$$

has a characteristic equation

$$
\frac{d y}{d x}=-b_{1}(x) y-h_{1}(x, y)
$$

(4) we consider under the initial condition $y\left(x_{0}\right)=\bar{y}_{0},\left(x_{0}, \bar{y}_{0}\right) \in S$, and we assume that the solution $y=y\left(x, x_{0}, \bar{y}_{0}\right)$ is defined on the set $I$. The equation

$$
\frac{\partial u}{\partial x}=\left(b_{2}(x) y+h_{2}\left(x, y, u, \frac{\partial u}{\partial y}\right)\right) \frac{\partial u}{\partial y}
$$

consider under the initial condition

$$
u(0, y)=\varphi(y)
$$

where $\varphi(y) \in \mathbb{C}^{2},\left(0,0, \varphi(0), \varphi^{\prime}(0)\right) \in E$; as known, problem (5), (6) for small $x,|y|$ has a unique solution $u(x, y)$ of class $\mathbb{C}^{2}(S)$. The equation

$$
\frac{\partial \nu}{\partial x}=\left(b_{3}(x) y+h_{3}(x, y)\right) \frac{\partial \nu}{\partial y}
$$

has a characteristic equation

$$
\frac{d y}{d x}=-b_{3}(x) y-h_{3}(x, y)
$$


Considering (8) under the initial condition $y\left(x_{0}\right)=\overline{\bar{y}}_{0}\left(x_{0}, \overline{\bar{y}}_{0}\right) \in S$ and assume that the solution $y=y\left(x, x_{0}, \overline{\bar{y}}_{0}\right)$ is defined on the set $I$.

Theorem. If in the diagonal system of first-order partial differential equations (1) the following conditions are satisfied:

(A) $b_{i}(x) \in \mathbb{C}^{2}(I), x \in I \equiv[0,+\infty), h_{i}(x, y) \in \mathbb{C}^{2}(S), h_{i}(x, 0)=0 ; i=(\overline{1,3})$;

(B) $h_{2}\left(x, y, u, \frac{\partial u}{\partial y}\right) \in \mathbb{C}^{2}(E), h_{2}\left(0,0, u, \frac{\partial u}{\partial y}\right)=0$ and satisfies the Lipschitz condition with respect to $\left(u, \frac{\partial u}{\partial y}\right)$ in the domain $E$; there is an inequality $u_{x x} u_{y y}-u_{x y}^{2} \neq 0$ and the solution $u\left(x, y, u, \frac{\partial u}{\partial y}\right)>0$ of equation (5), with the initial value (6), can be continued for $x>0,(x, y) \in S$;

(C) The inequality holds $b_{1}(x)<b_{2}(x)<b_{3}(x), x \in I ;\left|b_{i}(x)\right| \leq K_{i} \psi(x), x \in I$; $K_{i}>0, i=(\overline{1,3})$;

$\psi(x) \in \mathbb{C}(I), \psi(x)>0, \lim _{x \rightarrow+\infty} \psi(x)=0, \quad \int_{0}^{+\infty} \psi(x) d x=+\infty ;$

By definition, $q(x)=\int_{0}^{x} \psi(\tau) d \tau$;

There are limits $\lim _{x \rightarrow+\infty} \frac{1}{q(x)} \int_{0}^{x} \frac{\left(-b_{i}(\tau)\right)}{\psi(\tau)} d q(\tau)=\beta_{i}, i=1,3 ; \beta_{1}<0, \beta_{3}<0$;

(D) Inequalities hold: $h_{1}(x, y)<h_{2}\left(x, y, u, \frac{\partial u}{\partial y}\right)<h_{2}(x, y),(x, y) \in S$;

(E) $\left|h_{i}(x, y)\right|=\delta(x)|y|, i=1,3 ; \delta(x) \in \mathbb{C}(I), \delta(x)>0, \lim _{x \rightarrow+\infty} \frac{\delta(x)}{\psi(x)}=0 ;\left|\frac{\partial u}{\partial y}\right|<K$, $\left|h_{2}\left(x, y, u, \frac{\partial u}{\partial y}\right) \frac{\partial u}{\partial y}\right|=K \delta(x)|y|, \lim _{x \rightarrow+\infty} \frac{1}{q(x)} \int_{0}^{x} \frac{\left(-K b_{i}(\tau)\right)}{\psi(\tau)} d q(\tau)=\beta_{2}$, and the inequalities $\beta_{1}<$ $\beta_{2}<\beta_{3}$ are satisfied;

Then there exists a solution $\theta(x, y), u(x, y), \nu(x, y)$ of system (1), with initial value (2) such that $\sqrt{\theta^{2}(x, y)+u^{2}(x, y)+\nu^{2}(x, y)} \rightarrow 0$ as $x_{0} \rightarrow+\infty$.

Proof. Consider the solution $u(x, y)$ of equation (5) with the initial value $u(0, y)=\varphi(y)$. By condition $u(x, y)$, the solution is defined for $x \in I$ and $y \in(-\delta, \delta) \subset(c, d)$, where a sufficiently small number $\delta>0$. Consider equation (4) and solutions $y=y\left(x, x_{0}, \bar{y}_{0}\right)$ of equation (4), where $\left(x_{0}, \bar{y}_{0}\right) \in S$. From conditions A) and E) It follows that the zero solution to equation (4) is asymptotically stable as $x \rightarrow+\infty$. In fact, in (4), the equation of the first approximation has the form

$$
\frac{d y}{d x}=-b_{1}(x) y
$$

From condition A), C) it follows that for solving the equation of the first approximation we have the estimate

$$
|y(x)| \leq\left|y\left(x_{0}\right)\right| e^{\beta_{1}\left[q(x)-q\left(x_{0}\right)\right]}
$$

Using this estimate to represent the solution of equation (4) in the form of an integral equation, found by varying an arbitrary constant, for any $\varepsilon \in\left(0, \frac{\left|\beta_{1}\right|}{2}\right)$ we obtain the estimate

$$
|y(x)| \leq\left|y\left(x_{0}\right)\right| e^{\left(\beta_{1}+\varepsilon\right)\left[q(x)-q\left(x_{0}\right)\right]}
$$

This implies the asymptotic stability of the zero solution to equation (4). We assume that asymptotic stability occurs for the initial values $\left|\bar{y}_{0}\right|<\delta$. Take $\omega_{1}(y)$ and the integral 
$\bar{y}_{0} \theta\left(x, y, x_{0}\right)$ of equation (4) satisfying the conditions $\frac{\partial \theta}{\partial y}>0, \theta\left(0, y, x_{0}\right)=\omega_{1}(y), \omega_{1}(y)<$ $\varphi(y)$ and $\bar{y}_{0} \in(-\delta, \delta)$.

Then $\theta(x, y)=\theta\left(x, y, x_{0}\right)$ is a solution of equation (3) satisfying the condition $\theta(0, y)=$ $\omega_{1}(y),\left(x, y, \theta, \theta_{y}\right) \in E$, and $\theta\left(x, y, x_{0}\right) \rightarrow 0, x_{0} \rightarrow+\infty$.

Consider equation (8) and solutions $y=y\left(x, x_{0}, \overline{\bar{y}}_{0}\right)$ of equation $(8)$, where $\left(x_{0}, \overline{\bar{y}}_{0}\right) \in S$. Similarly to equation (4), it is established that condition A) and E) imply that the zero solution to equation (8) is asymptotically stable as $x \rightarrow+\infty$. We assume that asymptotic stability occurs for the initial values $\left|\overline{\bar{y}}_{0}\right|<\delta$. Take $\omega_{2}(y)$ and the integral $\overline{\bar{y}}_{0}=\nu\left(x, y, x_{0}\right)$ of equation (8) satisfying the conditions $\frac{\partial \nu}{\partial y}>0$ and $\nu\left(0, y, x_{0}\right)=\omega_{2}(y), \varphi(y)<\omega_{2}(y)$ and $\overline{\bar{y}}_{0} \in(-\delta, \delta)$. Then $\nu(x, y)=\nu\left(x, y, x_{0}\right)$ a solution of equation $(7)$ satisfying the condition $\nu\left(0, y_{0}\right)=\omega_{2}(y),\left(x, y, \theta, \theta_{y}\right) \in E$, and $\nu\left(x, y, x_{0}\right) \rightarrow 0, x_{0} \rightarrow+\infty$.

By virtue of conditions $\mathrm{C}$ ) and $\mathrm{D})$, the inequalities hold

$$
\left(b_{1}(x) y+h_{1}(x, y)\right) \frac{\partial \theta}{\partial y}<\left(b_{2}(x) y+h_{2}\left(x, y, u, \frac{\partial u}{\partial y}\right)\right) \frac{\partial u}{\partial y}<\left(b_{3}(x) y+h_{3}(x, y)\right) \frac{\partial \nu}{\partial y}
$$

in the domain $E$. By the choice of $\omega_{1}(y), \omega_{2}(y)$, the inequalities holds:

$$
\omega_{1}(y)<\varphi(y)<\omega_{2}(y), y \in(c, d),(x, y) \in S
$$

Consequently,

$\sqrt{\theta^{2}(x, y)+u^{2}(x, y)+\nu^{2}(x, y)} \rightarrow 0$ as $x_{0} \rightarrow+\infty$.

The theorem is proved.

\section{Results}

The paper considers a diagonal nonlinear system of first-order partial differential equations. The equations in the system are interconnected by differential inequalities and have initial values, the set of which is the initial values of the system and the initial values of the associated equations are selected appropriately. It is proved that the diagonal system under certain conditions has an infinitesimal solution in a neighborhood of an infinitely distant point.

\section{Acknowledgment}

The work was carried out with the support of grant financing: - Fundamental and applied research in mathematics on the topic "The investigation of the asymptotic stability of the solution and the development of asymptotic characteristics of a system of first-order partial differential equation", No. AP05132615.

\section{References}

[1] Kovalevskaya S., "Zusatze und Bemerkungen zu Laplace's Untersuchung uber die Gestalt der Saturnsringe"[Additions and Remarks on Laplace's Investigation of the Shape of Saturn's Rings], Astronomische Nachrichten, CXI (1885): 18-21

[2] Frobenius G., "Ueber das Pfaffsche Problem", Journal for die reine und angewandte Mathematik, (1877): 230-315

[3] Bendixcon I., " Demostration de l'existence de l'integrale d'une equation aux derives partielles lineaire", [Demonstration of the existence of the integral of a linear partial differential equation], Bull. Soc. Math. France, 24 (1896): 220-225. 
[4] Picard E., Traite d'analyse [Treatise on analysis] (Paris: Gauthier-Villars. , 1896)

[5] Goursat E., Lesons sur l'integration des equations aux derives partielles du premier ordre. 2ed. [Lessons on integrating first order partial differential equations.] (Paris, 1921), 77-81

[6] Caratheodory C., Variationsrechnung und partielle Differentialgleichungen erster Ordnung [Variational calculus and partial differential equations of first order] (Leipzig und Berlin:B. G. Teubner, 1935), 7-9

[7] Gunter N.M., Integrirovaniye uravneniy pervogo poryadka $v$ chastnykh proizvodnykh [Integration of first order partial differential equations] (L.-M., 1934)

[8] Kamke E., Spravochnik po differentsialnym uravneniyam v chastnyh proizvodnyh pervogo poryadka [Referense book in first-order partial differential equations]. (M.: Nauka, 1966), 260

[9] Wazewski T., "Sur l'unicite et la limitation des integrals des equations aux deriveespartielles du premier ordre", [On the uniqueness and the limitation of integrals of first order partial differential equations], Atti R. Accad. Naz. Lincei Rend. Cl. Sci.Fis. Mat. Nat., 18 (6) (1933): 372-376

[10] Wazewski T., "Ueber die Bedingungen der Existenz der Integrale partieller Differentialgleichungen erster Ordnung" [On the conditions of existence of the integrals of partial differential equations of the first order], Math. Zeit., VI.7-9 No.43. (1938): 522-532

[11] Wazewski T., "Sur l'appreciation du domain d'existence des integrals de l'equation aux derives partielles du premier ordre" [On the appreciation of the domain of existence of the integrals of the equation with partial derivatives of the first order], Ann. Soc. Polon. Math. VI.9, No.14 (1935): 149-177

[12] Perron O., "Ueber diejenigen Integrale linearer Differentialgleichungen, welche sich an einer Unbestimmtheitsstelle bestimmt verhalten"[On the integrals of linear differential equations which are determined at an uncertainty point], Math. Ann., VI.13, No 70 (1911): 1-32

[13] Plis A., "Characteristics of nonlinear partial differential equation", Bull.Acad. Polon. Sci., No 2. (1954): 419-422

[14] Digel E., "Uber die Bedingungen der Existenz der Integrale partieller Differentialgleichungen erster Ordnung" [On the conditions of existence of the integrals of the first order partial differential equations], Math Z, (1938): 445-451

[15] Haar A., "Zur Characteristikentheorie", [Characteristic Theory], Acta Sci. Math. Szeged, V.4. №2 (1928): 103-114

[16] Turski S., "Sur l'unicite et la limitation des integrals des equations aux derives partielles du premier ordre", [On the uniqueness and the limitation of integrals of first order partial derivative equations], Ann. Soc. Polon. Math., 120 (1933): $81-86$

[17] Petrovsky I.G., "O probleme Koshi dlya sistem uravneniy s chastnymi proizvodnymi", [On the Cauchy problem for systems of partial differential equations], Mat. Sbornik, V.2. No. 5. (1937)

[18] Nagumo M., "Ueber die Ungleichung $d u / d y>f(x, y, u, d u / d y)$ " [About the inequality $d u / d y>f(x, y, u, d u / d y)]$, Japan J. Math., 15 (1939): 51-56;

[19] Nagumo M., "Ueber die Differentialgleichung $y^{\prime \prime}=f\left(x, y, y^{\prime}\right)$ "'[About the differential equation $\left.y^{\prime \prime}=f\left(x, y, y^{\prime}\right)\right]$, Proc. Phys.-Math. Soc. Japan, 19 (3) (1937): 861-866;

[20] Nagumo M., "Ueber das Randwertproblem der nicht linearen gewohnlichen Differentialgleichungen zweiter Ordnung"[On the boundary value problem of the non-linear ordinary differential equations of the second order], Proc. Phys.-Math. Soc. Japan, 24 (1942): 845-851;

[21] Hartman P., "On exterior derivatives and solutions of ordinary differential equations", Trans. Amer. Math., Soc., 91 (1959): 277-292.

[22] Kamke E., Differentialgleichungen, Losungsmethoden und Losungen[Differential Equations, Solution Methods and Solutions] (Leipzig: II. Akademische Verlagsgesellschaft, 1959)

[23] Hartman P., Obyknovennye differentsialnye uravneniya [Ordinary differential equations] (M.:Mir, 1970): 719

[24] Courant R., Uravneniya s chastnymi proizvodnymi [Partial equations] (M: Mir, 1964), 845

[25] Petrovsky I.G., Lektsii ob uravneniyah s chastnymi proizvodnymi [Lectures in partial equations] 3rd ed. (M., 1961), 400

[26] Rashevsky P.K., Geometricheskaya teoriya s chastnymi proizvodnymi [Partial geometric theory] (M.-L., 1947) 
[27] Smirnov V., Kurs vysshei matematiki [Higher math course] V.4, 2nd part, (M.: Nauka, 1981), 551

[28] Stepanov V.V., The course of differential equations, 6-th ed. [Kurs differentsial'nykh uravneniy] (Nauka. Fizmatgiz, 1959)

[29] Yanenko N.N. and Rojdestvensky B.L., Sistemy kvazilineinyh uravneenii $i$ ih prilozhenie $k$ gazovoi dinamike [Systems of quaziliniear differential equations and their application to gas dynamics] VI.7-9, (M., 1978), 676 